\title{
Seed Germination in Tomato: A Focus on Interaction between Phytochromes and Gibberellins or Abscisic Acid
}

\author{
Marina Alves Gavassi' ${ }^{1}$, Gabriela Cabral Fernandes ${ }^{1}$, Carolina Cristina Monteiro', \\ Lázaro Eustáquio Pereira Peres ${ }^{2}$, Rogério Falleiros Carvalho ${ }^{*}$ \\ ${ }^{1}$ Departamento de Biologia Aplicada à Agropecuária, UNESP, Jaboticabal, Brazil \\ ${ }^{2}$ Departamento de Ciências Biológicas, ESALQ, Piracicaba, Brazil \\ Email: ${ }^{*}$ rfcarval@fcav.unesp.br
}

Received 10 May 2014; revised 8 June 2014; accepted 25 June 2014

Copyright (C) 2014 by authors and Scientific Research Publishing Inc.

This work is licensed under the Creative Commons Attribution International License (CC BY). http://creativecommons.org/licenses/by/4.0/

(c) (i) Open Access

\section{Abstract}

Separately, it is well-documented that phytochromes (phys), gibberellin (GA) and abscisic acid (ABA) strongly control the seed germination in tomato. However, we hipothesized that phys interact with GA or ABA during this response. Thus, we make an analysis of seed germination of $A B A$ deficient (sit), GA constitutive response (pro), phytochrome deficient (au) mutants as well as, specially, au sit and au pro double mutants of tomato incubated in the dark or light conditions during $120 \mathrm{~h} \mathrm{[12} \mathrm{h}$ intervals (i)]. Compared to $\mathrm{au}$, which severely reduced percentage germination $\left(\mathrm{G}_{\mathrm{i}} \%\right)$ and pro, which did not alter $\mathrm{G}_{\mathrm{i}} \%$, au pro showed in the light enhanced $\mathrm{G}_{\mathrm{i}} \%$ and germination speed index (GSI) besides the reduced average germination time (AGT). Moreover, in the dark, germination of au pro was similar to pro. These results indicate that the mechanisms by which GA modulate germination in tomato are light dependent through the phy signaling, whereas intermediary values of $\mathrm{G}_{\mathrm{i}} \%$, GSI and AGT in dark and light of au sit compared to au and sit single mutants indicate an additive effect of the $a u$ and sit mutations, suggesting that ABA and phy may act through the parallel signaling pathway.

\section{Keywords}

Abscisic Acid, Gibberellins, Phytochromes, Seed Germination, Tomato

\section{Introduction}

Classic factors that modulate seed germination in a wide range of species include the hormones gibberellin (GA)

*Corresponding author.

How to cite this paper: Gavassi, M.A., Fernandes, G.C., Monteiro, C.C., Peres, L.E.P. and Carvalho, R.F. (2014) Seed Germination in Tomato: A Focus on Interaction between Phytochromes and Gibberellins or Abscisic Acid. American Journal of Plant Sciences, 5, 2163-2169. http://dx.doi.org/10.4236/ajps.2014.514229 
and abscisic acid (ABA) and phytochromes (phys), which are converted from their inactive red (R)-light-absorbing form (Pr) into its active far-red (RF)-light-absorbing form (Pfr) [1]. However, although it is well known that separately GA, ABA and phy modulate seed germination [2], these factors can strongly interact each other. For example, during seed germination in Arabidopsis, the degradation of PHYTOCHROME INTERACTING FACTOR 3-LIKE5 (PIL5) (also called PIF1) by phy reverses the action of PIL5, reducing ABA levels and increasing GA levels, and therefore, decreasing the DELLA proteins, GA negative signaling components [3] [4]. In addition, the DELLA-dependent accumulation of endogenous ABA levels stimulates the expression of ABI3, an embryonic transcription factor that is necessary to repress germination under FR conditions [5]-[7].

However, the regulatory loops between light and GA and ABA signaling are still very complex since the intricate molecular and biochemical signaling pathways of these molecules are dependent on species, temperature, and light [2] [8]. For example, it is known that Arabidopsis seeds germinate poorly in darkness, but GA can promote seed germination even in the dark [9]. In barley seeds, the expression of GA3ox2, a GA biosynthetic gene, increased rapidly and continued to increase up to 24-h imbibition in after-ripened grains in both light and dark conditions [10]. Thus, there are an overwhelming number of molecular and biochemical questions about the mechanisms behind seed germination. For example, which hormones and photoreceptors control the germination response, how do they do it, and how do they interact with one another? Are these interactions light dependent? In order to answer many of these questions, conducting a physiological dissection of these tools prior to following the molecular approach can provide answers to many of the above questions. Thus, hormonal and photomorphogenic mutants and hormonal-photomorphogenic double mutants have served as important tools. In the present study, we used GA constitutive response, ABA-deficient or phy-deficient mutants, as well as GAphy or ABA-phy double mutants of tomato to explore the physiology of seed germination.

\section{Materials and Methods}

\section{Plant Material and Seed Germination Assays}

We used seeds of tomato (Solanum lycopersicum) mutants introgressed into the cultivar Micro-Tom (MT) [11]: aurea or au (phy-deficient) [12], sitiens or sit (ABA-deficient) [13], and procera or pro (GA constitutive response) [14] which were kindly provided by R. Chetelat (The C.M. Rick Tomato Genetics Resource Center, Davis, USA). We also used au sit and au pro double mutants previously constructed [15]. MT was used as control. Seed germination assays of photomorphogenic, hormonal, and double mutants and MT control were performed by sowing seeds onto two wet filter papers in transparent or black plastic boxes. The experiments were conducted in a growth chamber $\left(25^{\circ} \mathrm{C}, 16 \mathrm{~h}\right.$ photoperiod, $55 \mu \mathrm{mol}$ photons $\left.\mathrm{m}^{-2} \cdot \mathrm{s}^{-1} \mathrm{PAR}\right)$. For the dark treatment, seeds were counted in a dark room under a dim green safelight. We used three replicates of 50 seeds and calculated the daily (i) (12/12 h for $120 \mathrm{~h})$ percentage of seeds that germinated $\left(\mathrm{G}_{\mathrm{i}} \%\right)$, besides the $\mathrm{G}_{\mathrm{f}} \%$, where $\mathrm{f}$ is final percentage (after $120 \mathrm{~h}$ ). The calculation may be expressed using the following formula:

$$
\mathrm{G}_{\mathrm{i}} \% \text { or } \mathrm{G}_{\mathrm{f}} \%=\left(n_{i} / N\right) \times 100
$$

where $n_{i}$ is the number of seeds germinated every $12 \mathrm{~h}$, and $N$ is the number of seeds included in the test, and then $\mathrm{G}_{\mathrm{f}} \%$ is final percentage (after $120 \mathrm{~h}$ ) of seeds that germinated.

We used the following formulas to calculate the germination speed index (GSI) and average germination time (AGT):

$$
\mathrm{GSI}=\sum\left(n_{i} / t_{i}\right)
$$

where $t_{i}$ is day $i$

$$
\mathrm{AGT}=\sum\left(t_{i} \cdot n_{i}\right) / \sum n
$$

$\mathrm{T}_{50}$ is the time it takes to reach $50 \%$ germination. This, in turn, is calculated according to the following formula [16] [17]:

$$
\mathrm{T}_{50}=t_{i}+\left[(N / 2)-n_{i}\right]\left(t_{j}-t_{i}\right) /\left(n_{j}-n_{i}\right)
$$

where $N$ is the final number of seeds that germinated and $n_{i}$ and $n_{j}$ are the cumulative number of seeds germinated by adjacent counts at times $t_{i}$ and $t_{j}$ when $n_{i}<N / 2<n_{j}$. 
To observe seed dormancy break as affected by GA in au mutant, seeds were incubated in light and dark conditions during $120 \mathrm{~h}$ with $100 \mu \mathrm{M}$ GA.

Germination was defined as the visible emergence of the radicle through the seed coat [18] [19].

The data were submitted to statistical analysis by using analysis of variance and Tukey’s test at a 5\% significance level.

\section{Results and Discussion}

In this study, we used phy, ABA, and GA mutants, as well as double mutants displaying both phy and ABA or both phy and GA mutations, to explore the photomorphogenic and hormonal control of seed germination in tomato. As we expected, given the light treatment the ABA-deficient mutant, sit, showed a constant increase of $\mathrm{G}_{\mathrm{i}} \%$ after $60 \mathrm{~h}$ (Figure 1(A)) and a reduction in GSI, AGT, and $\mathrm{T}_{50}$ (Table 1) compared with the MT control. In fact, in

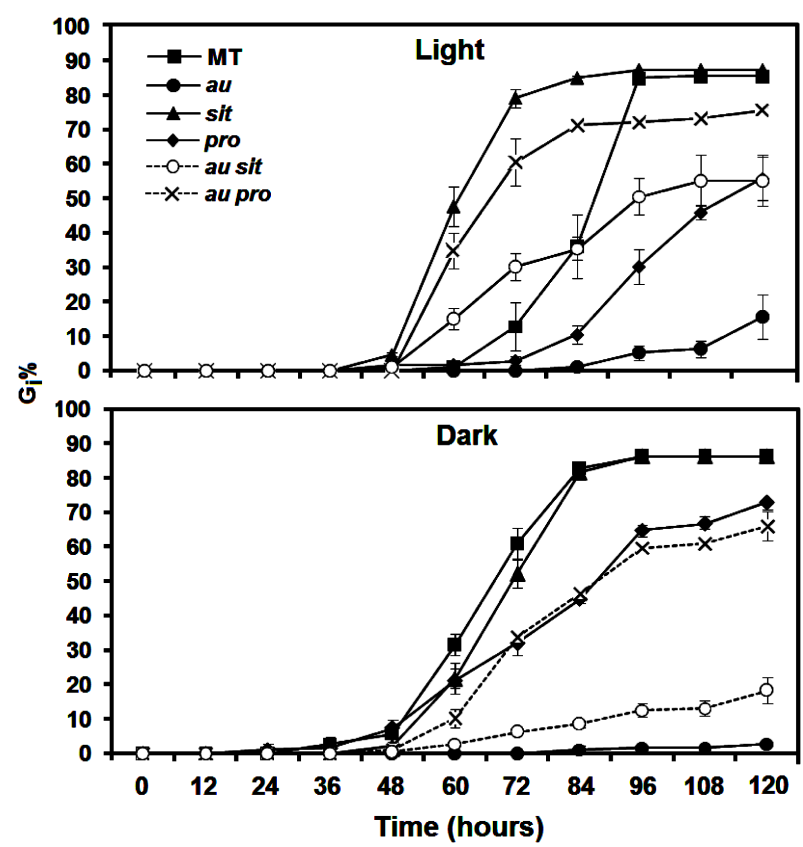

Figure 1. Seed germination percentage at $12 \mathrm{~h}$ intervals (i) $\left(\mathrm{G}_{\mathrm{i}} \%\right)$ of photomorphogenic and/or hormonal mutants incubated in light and dark conditions during 120 hours. Data are means \pm SE.

Table 1. Germination speed index (GSI), average germination time (AGT), time to reach $50 \%$ germination $\left(\mathrm{T}_{50}\right)$ and final germination percentage $\left(\mathrm{G}_{\mathrm{f}} \%\right)$ obtained from seeds of photomorphogenic and/or hormonal mutants incubated in light (L) and dark (D) conditions during $120 \mathrm{~h}$.

\begin{tabular}{cccccccccc}
\hline \multirow{2}{*}{ Genotypes } & \multicolumn{2}{c}{ GSI } & \multicolumn{2}{c}{ AGT } & \multicolumn{2}{c}{$\mathrm{T}_{50}$} & \multicolumn{2}{c}{$\mathrm{G}_{\mathrm{f}} \%$} \\
\cline { 2 - 9 } & $\mathrm{L}$ & $\mathrm{D}$ & $\mathrm{L}$ & $\mathrm{D}$ & $\mathrm{L}$ & $\mathrm{D}$ & $\mathrm{L}$ & $\mathrm{D}$ \\
\hline MT & $0.56^{\mathrm{bc}}$ & $0.74^{\mathrm{a}}$ & $89.08^{\mathrm{ab}}$ & $70.40^{\mathrm{b}}$ & $84.82^{\mathrm{ab}}$ & $64.89^{\mathrm{b}}$ & $98.00^{\mathrm{a}}$ & $100.00^{\mathrm{a}}$ \\
au & $0.08^{\mathrm{e}}$ & $0.02^{\mathrm{d}}$ & $103.95^{\mathrm{a}}$ & $104.00^{\mathrm{a}}$ & - & - & $18.00^{\mathrm{c}}$ & $3.33^{\mathrm{d}}$ \\
pro & $0.33^{\mathrm{d}}$ & $0.58^{\mathrm{b}}$ & $100.00^{\mathrm{a}}$ & $80.39^{\mathrm{b}}$ & $105.93^{\mathrm{a}}$ & $82.04^{\mathrm{a}}$ & $64.00^{\mathrm{b}}$ & $84.67^{\mathrm{b}}$ \\
sit & $0.76^{\mathrm{a}}$ & $0.69^{\mathrm{a}}$ & $67.04^{\mathrm{c}}$ & $74.00^{\mathrm{b}}$ & $59.17^{\mathrm{c}}$ & $68.44^{\mathrm{b}}$ & $100.00^{\mathrm{a}}$ & $100.00^{\mathrm{a}}$ \\
au pro & $0.63^{\mathrm{ab}}$ & $0.49^{\mathrm{b}}$ & $70.46^{\mathrm{c}}$ & $81.15^{\mathrm{ab}}$ & $64.71^{\mathrm{bc}}$ & $80.71^{\mathrm{a}}$ & $86.67^{\mathrm{ab}}$ & $76.67^{\mathrm{b}}$ \\
au sit & $0.42^{\mathrm{cd}}$ & $0.12^{\mathrm{c}}$ & $78.33^{\mathrm{bc}}$ & $89.53^{\mathrm{ab}}$ & $98.5^{\mathrm{a}}$ & - & $63.33^{\mathrm{b}}$ & $21.33^{\mathrm{c}}$ \\
\hline
\end{tabular}

*In a column, means followed by the same letter are not significantly different by the Tukey test at $5 \%$ of probability. Following N/2 (Coolbear et al., 1984; Farooq et al., 2005) [16] [17], the absent data mean that genotypes did not reach $\mathrm{T}_{50}$. 
contrast with wild-type seeds, seeds of sit always readily germinate and even exhibit viviparous germination in overripe fruits [20]. Although the GSI and AGT data show the rapidity with which sit can germinate despite its ABA deficiency, $\mathrm{G}_{\mathrm{f}} \%$ and $\mathrm{G}_{\mathrm{i}} \%$ after $120 \mathrm{~h}$ did not differ from that of MT (Table 1). Moreover, in the dark condition, $\mathrm{G}_{\mathrm{i}} \%$ from 48 to $120 \mathrm{~h}$ (Figure 1(B)), AGT, $\mathrm{T}_{50}$, and especially GSI (Table 1) did not differ from MT. This finding indicates that ABA deficiency in sit has a complex mechanism that is light dependent during germination and that remains to be explored using molecular and biochemical approaches.

To investigate whether the constitutive GA response conferred by the pro affected germination, Bassel et al. [13] dissected the embryo axes from the endosperm after $4 \mathrm{~h}$ of imbibition and verified that the pro germinated the fastest of all the wide types. However, we observed that in both the dark and the light condition in intact seeds, pro reduced $\mathrm{G}_{\mathrm{i}} \%$ from 60 to $120 \mathrm{~h}$ (Figure 1) and also reduced GSI and $\mathrm{G}_{\mathrm{f}} \%$. The AGT was similar to that in MT (Table 1), and $T_{50}$ was increased in the dark. Thus, irrespective of whether constitutive GA response is the mechanism by which pro accelerates germination in dissected seeds, the pro mutation is not fully capable of mediating a rapid breaking of coat dormancy. In other words, although GA profoundly influences seed germination and the pro mutation regulates GA responses within the embryo [13], the coat modifications for radicle protrusion appear not to depend on the GA constitutive response. Further detailed inspections of seed biochemistry and the anatomy of pro are necessary to explain the delayed germination in this mutant.

One of the more noticeable effects of the $a u$ mutation is a severe delay in seed germination [15] [21] due to a deficiency in phytochrome chromophore biosynthesis. We present novel observations relating to this effect regarding $\mathrm{G}_{\mathrm{i}} \%$ (Figure 1), GSI, and $\mathrm{G}_{\mathrm{f}} \%$ (Table 1), all of which were reduced in the light and the dark, whereas AGT increased compared to that in MT (Table 1). It is remarkable to note that the severity of the germination delay in the $a u$ mutation is intensified in the dark, indicating that although $a u$ is phytochrome deficient, either the low phytochrome signaling or the presence of other photoreceptors such as cryptochromes is sufficient to promote germination in this mutant.

Intriguingly, compared with au and pro, the au pro double mutant in the light condition showed an enhanced $\mathrm{G}_{\mathrm{i}} \%$ from 60 to $120 \mathrm{~h}$ (Figure 1(A)), increased GSI (Table 1), and reduced AGT (Table 1). In the dark, this genotype showed a similar GSI and AGT to pro and $a u$, on top of the existing similarity between AGT and pro. One might expect to see an additive effect of reduced germination of $a u$ and pro in double mutants, but in the light, the phy deficiency and GA constitutive response improve seed germination. Certainly, these results need to be interpreted carefully, as there is interaction between light and GA at virtually every stage of plant growth [13] [22]. Furthermore, and particularly during seed germination, the mechanisms by which GA is involved in light signaling are quite complex. For example, previous findings in Arabidopsis indicate that phytochromes promote seed germination by lowering the level of DELLA proteins and increasing the level of bioactive GA [3] [4].

Thus, at least in the light, it is plausible to suggest that in tomato the au mutant shows reduced germination because the phy deficiency does not induce GA activities; however, a hormonal quantification was not carried out in this mutant. So far, although exogenous GA did not recover $a u$ germination in the light to MT levels, au seems trigger more sensitivity to GA in the dark (Figure 2), indicating that tomato does not have a linear induction of GA by phy during germination. In fact, although the GA constitutive response of pro recovers $a u$ germination in $a u$ pro, the delayed germination in pro shows that the GA modulation of seed germination in tomato occurs only under specific conditions or that GA functions are highly redundant. Further evidence is that in the dark, $\mathrm{G}_{\mathrm{i}} \%$ (Figure 1(B)), GSI, AGT, and $\mathrm{G}_{\mathrm{f}} \%$ (Table 1) are similar in pro and au pro. In addition, there is an intricate GA signaling pathway in pro or au pro, as pro contains reduced concentrations of GAs despite its constant response to this hormone [23].

In the light and dark conditions, the intermediary values of $\mathrm{G}_{\mathrm{i}} \%$ (Figure 1), GSI, and $\mathrm{G}_{\mathrm{f}} \%$ (Table 1) of au sit compared with $a u$ and sit suggest that there is an additive effect of both mutations on germination. However, only in the light condition, AGT of au sit seemed to show an epistatic effect of sit, as sit and au sit are similar (Table 1). Thus, although an additive interaction indicates that light and ABA have independent pathways during tomato germination, AGT of au sit revealed that the mechanisms by which phy and ABA control germination can be dependent on one another. However, data regarding how ABA is part of light signaling are still very scarce in tomato. Majority of the currently available information relates to the separate effects of phy [24] [25] or ABA [26] [27].

A more detailed analysis of particular aspects of pro, such as the reduced concentrations of GA and constitutive responses to this hormone [23], will clarify the mechanism for such responses and will improve our knowledge of the role of GA in seed germination in tomato. The results of au pro raise questions about the mechanisms 


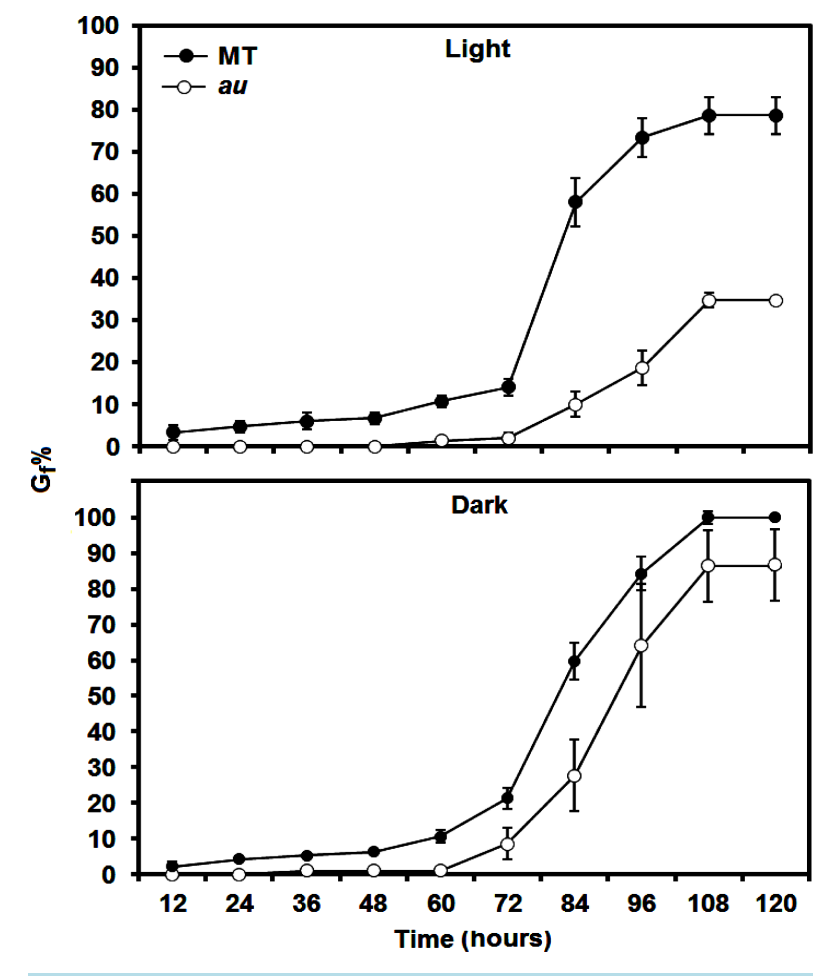

Figure 2. Seed germination percentage at $12 \mathrm{~h}$ intervals of $a u$ mutant incubated in light and dark conditions during 120 hours. Over time, seeds were treated with $100 \mu \mathrm{M}$ GA. Note that GA did not induce dormancy break to MT levels, but seems trigger more sensitivity to GA in the dark. Data are means \pm SE.

of GA participation in light signaling during germination. For example, which photoreceptors interact with GA, how do they interact, and can they regulate GA levels? These questions may be asked about ABA and other hormonal classes as well, as brassinosteroids, auxin [28] [29], cytokinin [30], and ethylene [31] are clearly involved in germination. However, the most important issue of the molecular interpretation of light signaling and hormone interactions during germination remains to be elucidated by future research.

\section{Acknowledgements}

The financial support has been provided by FAPESP (grant number 02/00329-8 and fellowship number 03/12416-5) and CNPq (grant number 475494/03-2 and fellowship number 308075/03-0).

\section{References}

[1] Li, C.J., Liu, Z.J., Zhang, Q.R., Wang, R.Z., Xiao, L.T., Ma, H., Chong, K. and Xu, Y.Y. (2012) SKP1 Is Involved in Abscisic Acid Signalling to Regulate Seed Germination, Stomatal Opening and Root Growth in Arabidopsis thaliana. Plant and Cell Environment, 35, 952-965. http://dx.doi.org/10.1111/j.1365-3040.2011.02464.x

[2] Seo, M., Nambara, E., Choi, G. and Yamaguchi, S. (2009) Interaction of Light and Hormone Signals in Germinating Seeds. Plant Molecular Biology, 69, 463-472. http://dx.doi.org/10.1007/s11103-008-9429-y

[3] Oh, E., Yamaguchi, S., Hu, J., Yusuke, J., Jung, B., Paik, I., Lee, H.S., Sun, T.-P., Kamiya, Y. and Choi, G. (2007) PIL5, a Phytochrome-Interacting bHLH Protein, Regulates Gibberellin Responsiveness by Binding Directly to the GAI and RGA Promoters in Arabidopsis Seeds. The Plant Cell, 19, 1192-1208. http://dx.doi.org/10.1105/tpc.107.050153

[4] Oh, E., Kang, H., Yamaguchi, S., Park, J., Lee, D., Kamiya, Y. and Choi, G. (2009) Genome-Wide Analysis of Genes Targeted by PHYTOCHROME INTERACTING FACTOR 3-LIKE5 during Seed Germination in Arabidopsis. Plant Cell, 21, 403-419. http://dx.doi.org/10.1105/tpc.108.064691

[5] Lopez-Molina, L., Mongrand, S. and Chua, N.H. (2001) A Postgermination Developmental Arrest Checkpoint Is Me- 
diated by Abscisic Acid and Requires the ABI5 Transcription Factor in Arabidopsis. Proceedings of the National Academy of Sciences of the United States of America, 98, 4782-4787. http://dx.doi.org/10.1073/pnas.081594298

[6] Lopez-Molina, L., Mongrand, S., McLachlin, D.T., Chait, B.T. and Chua, N.H. (2002) ABI5 Acts Downstream of ABI3 to Execute an ABA-Dependent Growth Arrest during Germination. The Plant Journal, 32, 317-328. http://dx.doi.org/10.1046/j.1365-313X.2002.01430.x

[7] Piskurewicz, U., Tureckova, V., Lacombe, E. and Lopez-Molina, L. (2009) Far-Red Light Inhibits Germination through DELLA-Dependent Stimulation of ABA Synthesis and ABI3 Activity. Embo Journal, 28, 2259-2271. http://dx.doi.org/10.1038/emboj.2009.170

[8] Dechaine, J.M., Gardner, G. and Weinig, C. (2009) Phytochromes Differentially Regulate Seed Germination Responses to Light Quality and Temperature Cues during Seed Maturation. Plant and Cell Environment, 32, 1297-1309. http://dx.doi.org/10.1111/j.1365-3040.2009.01998.x

[9] Cao, D.N., Hussain, A., Cheng, H. and Peng, J.R. (2005) Loss of Function of Four DELLA Genes Leads to Light- and Gibberellin-Independent Seed Germination in Arabidopsis. Planta, 223, 105-113. http://dx.doi.org/10.1007/s00425-005-0057-3

[10] Gubler, F., Hughes, T., Waterhouse, P. and Jacobsen, J. (2008) Regulation of Dormancy in Barley by Blue Light and After-Ripening: Effects on Abscisic Acid and Gibberellin Metabolism. Plant Physiology, 147, 886-896. http://dx.doi.org/10.1104/pp.107.115469

[11] Carvalho, R.F., Campos, M.L., Pino, L.E., Crestana, S.L., Zsogon, A., Lima, J.E., Benedito, V.A. and Peres, L.E.P. (2011) Convergence of Developmental Mutants into a Single Tomato Model System: "Micro-Tom" as an Effective Toolkit for Plant Development Research. Plant Methods, 7, 18. http://dx.doi.org/10.1186/1746-4811-7-18

[12] Muramoto, T., Kami, C., Kataoka, H., Iwata, N., Linley, P.J., Mukougawa, K., Yokota, A. and Kohchi, T. (2005) The Tomato Photomorphogenetic Mutant, aurea, Is Deficient in Phytochromobilin Synthase for Phytochrome Chromophore Biosynthesis. Plant and Cell Physiology, 46, 661-665. http://dx.doi.org/10.1093/pcp/pci062

[13] Taylor, I.B., Burbidge, A. and Thompson, A.J. (2000) Control of Abscisic Acid Synthesis. Journal of Experimental Botany, 51, 1563-1574. http://dx.doi.org/10.1093/jexbot/51.350.1563

[14] Bassel, G.W., Mullen, R.T. and Bewley, J.D. (2008) Procera Is a Putative DELLA Mutant in Tomato (Solanum lycopersicum): Effects on the Seed and Vegetative Plant. Journal of Experimental Botany, 59, 585-593. http://dx.doi.org/10.1093/jxb/erm354

[15] Carvalho, R.F., Quecini, V. and Peres, L.E.P. (2010) Hormonal Modulation of Photomorphogenesis-Controlled Anthocyanin Accumulation in Tomato (Solanum lycopersicum L. cv Micro-Tom) Hypocotyls: Physiological and Genetic Studies. Plant Science, 178, 258-264. http://dx.doi.org/10.1016/j.plantsci.2010.01.013

[16] Coolbear, P., Francis, A. and Grierson, D. (1984) The Effect of Low Temperature Pre-Sowing Treatment on the Germination Performance and Membrane Integrity of Artificially Aged Tomato Seeds. Journal of Experimental Botany, 35, 1609-1617. http://dx.doi.org/10.1093/jxb/35.11.1609

[17] Farooq, M., Basra, S.M.A., Ahmad, N. and Hafeez, K. (2005) Thermal Hardening: A New Seed Vigor Enhancement Tool in Rice. Journal of Integrative Plant Biology, 47, 187-193. http://dx.doi.org/10.1111/j.1744-7909.2005.00031.x

[18] Maguire, J.D. (1962) Speed of Germination-Aid in Selection and Evaluation for Seedling Emergence and Vigor. Crop Science, 2, 176-177. http://dx.doi.org/10.2135/cropsci1962.0011183X000200020033x

[19] Galmés, J., Medrano, H. and Flexas, J. (2006) Germination Capacity and Temperature Dependence in Mediterranean Species of the Balearic Islands. Investigación Agraria: Sistemas y Recursos Forestales, 15, 88-95.

[20] Groot, S.P.C. and Karssen, C.M. (1992) Dormancy and Germination of Abscisic Acid-Deficient Tomato Seeds: Studies with the sitiens Mutant. Plant Physiology, 99, 952-958. http://dx.doi.org/10.1104/pp.99.3.952

[21] Georghiou, K. and Kendrick, R.E. (1991) The Germination Characteristics of Phytochrome-Deficient aurea Mutant Tomato Seeds. Physiologia Plantarum, 82, 127-133. http://dx.doi.org/10.1111/j.1399-3054.1991.tb02912.x

[22] Hartweck, L.M. (2008) Gibberellin Signaling. Planta, 229, 1-13. http://dx.doi.org/10.1007/s00425-008-0830-1

[23] Van Tuinen, A., Peters, A.H.L.J., Kendrick, R.E., Zeevaart, J.A.D. and Koornneef, M. (1999) Characterisation of the Procera Mutant of Tomato and the Interaction of Gibberellins with End-of-Day Far-Red Light Treatments. Physiologia Plantarum, 106, 121-128. http://dx.doi.org/10.1034/j.1399-3054.1999.106117.x

[24] Shichijo, C., Katada, K., Tanaka, O. and Hashimoto, T. (2001) Phytochrome A-Mediated Inhibition of Seed Germination in Tomato. Planta, 213, 764-769. http://dx.doi.org/10.1007/s004250100545

[25] Appenroth, K.J., Lenk, G., Goldau, L. and Sharma, R. (2006) Tomato Seed Germination: Regulation of Different Response Modes by Phytochrome B2 and Phytochrome A. Plant, Cell and Environment, 29, 701-709. http://dx.doi.org/10.1111/j.1365-3040.2005.01455.x

[26] Bradford, K.J., Downie, A.B., Gee, O.H., Alvarado, V., Yang, H. and Dahal, P. (2003) Abscisic Acid and Gibberellin 
Differentially Regulate Expression of Genes of the SNF1-Related Kinase Complex in Tomato Seeds. Plant Physiology, 132, 1560-1576. http://dx.doi.org/10.1104/pp.102.019141

[27] de Castro, R.D. and Hilhorst, H.W.M. (2006) Hormonal Control of Seed Development in GA- and ABA-Deficient Tomato (Lycopersicon esculentum Mill. cv. Moneymaker) Mutants. Plant Science, 170, 462-470. http://dx.doi.org/10.1016/j.plantsci.2005.09.014

[28] Park, J., Kim, Y.S., Kim, S.G., Jung, J.H., Woo, J.C. and Park, C.M. (2011) Integration of Auxin and Salt Signals by the NAC Transcription Factor NTM $_{2}$ during Seed Germination in Arabidopsis. Plant Physiology, 156, 537-549. http://dx.doi.org/10.1104/pp.111.177071

[29] Ryu, H. and Hwang, I. (2013) Brassinosteroids in Plant Developmental Signaling Networks. Journal of Plant Biology, 56, 267-273. http://dx.doi.org/10.1007/s12374-013-0298-9

[30] Wang, Y.P., Li, L., Ye, T.T., Zhao, S.J., Liu, Z., Feng, Y.Q. and Wu, Y. (2011) Cytokinin Antagonizes ABA Suppression to Seed Germination of Arabidopsis by Downregulating ABI5 Expression. Plant Journal, 68, 249-261. http://dx.doi.org/10.1111/j.1365-313X.2011.04683.x

[31] Lin, Y.C., Yang, L., Chen, D.D., Zu, Y.G. and Tang, Z.H. (2013) A Role for Ethylene-Insensitive3 in the Regulation of Hydrogen Peroxide Production during Seed Germination under High Salinity in Arabidopsis. Acta Physiologiae Plantarum, 35, 1701-1706. http://dx.doi.org/10.1007/s11738-012-1176-7

\section{Abbreviations}

AGT: average germination time

GSI: germination speed index

GA: gibberellin

ABA: abscisic acid

phy: phytochrome 
Scientific Research Publishing (SCIRP) is one of the largest Open Access journal publishers. It is currently publishing more than 200 open access, online, peer-reviewed journals covering a wide range of academic disciplines. SCIRP serves the worldwide academic communities and contributes to the progress and application of science with its publication.

Other selected journals from SCIRP are listed as below. Submit your manuscript to us via either submit@scirp.org or Online Submission Portal.
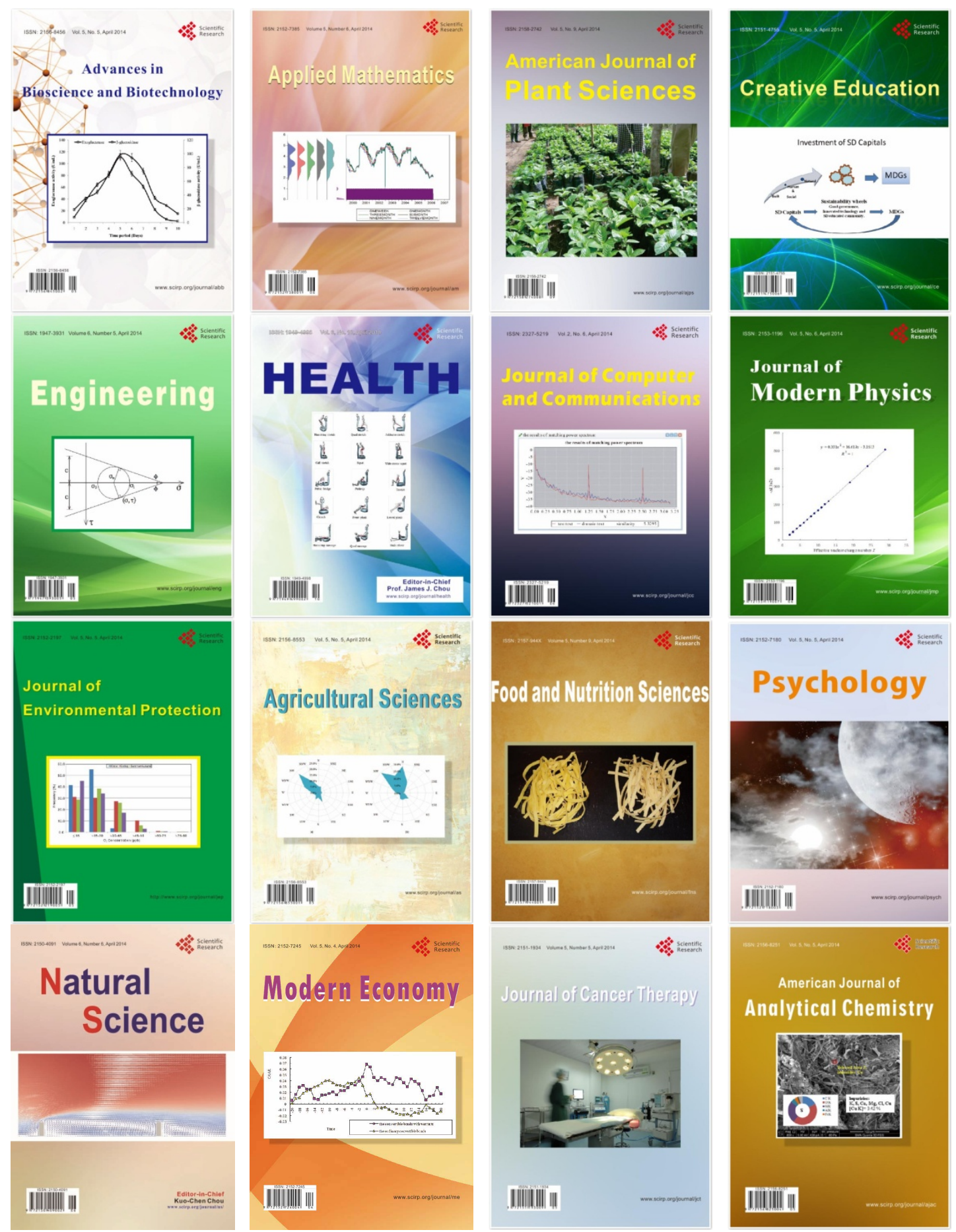